\title{
その場加熱実験と環境電子顕微鏡法
}

\section{In-situ heating experiments and environmental electron microscopy}

\author{
佐々木 勝寛*. 荒井 重勇**. 着本 享***. 坂 公恭**** \\ Katsuhiro SASAKI*, Shigeo ARAI**, Susumu TSUKIMOTO*** and Hiroyasu SAKA****
}

\section{1. はじめに}

その場観察法は, 透過電子顕微鏡内で材料の環境変化に対 する応答を調べることができる，非常にユニークで強力な実 験手法である。その場観察法では, 加熱・冷却, 引張・圧縮 などの応力印加など, 試料への状態を制御可能でかつ測定可 能な状況で変更することができるように設計された特別な試 料ステージを使用する。透過電子顕微鏡を用いるこの手法で は，材料の変化過程のメカニズムを理解することができる直 接的な情報を十分に高い空間分解能で得ることができ，材料 学者を魅了してきた。この高い空間分解能は, 他の手法が材 料中の変化過程の平均的な情報のみを与えるのに対して, 非 常に大きな優位点となる。特に最新の透過電子顕微鏡を用い ると，材料微細構造の变化を定性的に捉えるのみならず，材 料中のさまざまな物理的・化学的な変化の動的過程, 例え ば, 結晶欠陥の動的役割などに関する結晶学的情報や組織学 的情報を定量的に取得することができる。また，複数の一連 の試料をそれぞれ条件を変えながら実験を行った後にその結 果を測定し, 反応過程を推測するという従来の手法では, 試 料処理過程などの事後の外的な力による, 測定しようとして いる現象への影響を絶えず考慮しなければならないが，その 場観察法は同一の試料の微細構造を連続して観察するため, このような影響を回避できる。その場観察法は, 材料の性質 を示す, 微細構造変化と温度, 応力, 環境などの関係の直接 的な理解を可能とする。このようなその場観察法のうち，ガ スあるいは水䨌囲気中で行う手法が環境電子顕微鏡法であ る。

本稿では，著者らがかかわったその場観察法のうち，真空 中加熱を主体としたその場観察（その場加熱実験）の成果の 紹介と, 近年, 名古屋大学反応科学超高圧電子顕微鏡におい て取組んでいる環境電子顕微鏡法の一つである, ガス雲囲気 中その場加熱実験に関する結果を取上げる。

\section{2. 装置的な発展過程とその分類}

透過電子顕微鏡は, 1930 年代初頭にKnollの研究室で Ruskaらにより完成された ${ }^{1)}$, $)$ 。Ruskaらは, 1942 年には試
料室へガスを導入する機構の開発を行い, 気体による電子顕 微鏡像の鮮明度の変化を観察している3)。これは, 試料加熱 装置の開発に先立つもので, この事実は, 環境電子顕微鏡の 開発が, その場加熱実験に先立っていたという興味深い歴史 を示す。

その後, 1950 年代に試料加熱装置の開発が行われ，日本 では高橋らによる伝熱型 ${ }^{4)}$,5) や，橋本らによる ${ }^{6)}$ タングス テンフィラメントによる直熱型加熱ホルダの開発が行われ た。これらはガスを試料室ヘリークさせる機構と組合されて おり, 環境セルのさきがけの装置でもある。その後, 世界的 にさまざまな構造の加熱装置が作られた ${ }^{7), 8)}$ 。直熱型ホルダ は, 試料に直接接触させた加熱体, あるいは試料そのものに 電流を流し加熱する構造を持つ。このため, 迅速な加熱冷却 が可能で高温までの加熱が容易である。極初期のものでも, $2000^{\circ} \mathrm{C}$ 超を達成している ${ }^{6)}$ 。その一方で, 電子ビーム近傍を 加熱電流が流れるため, 加熱電流による像への影響を避ける ことができないという問題がある。伝熱型加熱ホルダは, 試 料ステージ周囲に加熱体を配し加熱炉を形成し，発熱体から の熱伝導により試料を加熱する。このため, 加熱ヒータを二 重巻きにすることにより, 加熱電流による像のシフトを避け ることができ, しかも試料傾斜機構を組込みやすいという構 造的利点がある。現在では，ほとんどすべての加熱ホルダが 伝熱型である。しかし，加熱体積が大きくなることにより熱 ドリフトが安定するまでに長い時間が必要となり, また, 炉 からの輻射による鏡体の加熱の問題などにより最高加熱温度 が $1000^{\circ} \mathrm{C}$ 前後に制限されている。

1980 年代になり, 電子顕微鏡の分解能が原子レベルに到 達すると，伝熱型の加熱ホルダの熱ドリフトの大きさや加熱 温度の制限が問題となり, 再び直熱型の加熱ホルダが注目

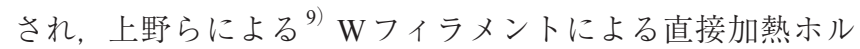
ダ (上野-坂ホルダ) が開発された。このホルダは後述する ように高温での熱安定性が非常に高く, 我々は, このホルダ を用いてさまざまな界面現象の観察を行った。

ガス雲囲気中でその場加熱実験を行う環境電子顕微鏡法で は，顕微鏡の真空を乱さないで試料周囲にガス雲囲気を保つ 環境セルを用いる。加熱装置と環境セルを組合せたその場実

*名古屋大学工学研究科量子工学専攻（ $\bar{T} 464-8603$ 愛知県名古屋市不老町)。Quantum Engineering, Nagoya University (Furo-cho, Chikusaku, Nagoya-shi, Aichi 464-8603).

**名古屋大学 エコトピア科学研究所 (名古屋市)。EcoTopia Science Institute, Nagoya University (Nagoya-shi, Aichi).

***東北大学 原子分子材料科学高等研究機構（仙台市）。Advanced Institute for Materials Research, Tohoku University (Sendai-shi, Miyagi).

****名古屋大学名誉教授 Emeritus Professor, Nagoya University.

受付日：平成 25 年 9 月 8 日 受理日：平成 25 年 10 月 20 日 


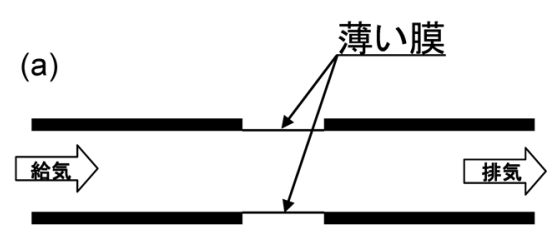

図 1 （a）Window型および（b）絞制限型環境セルの概念図
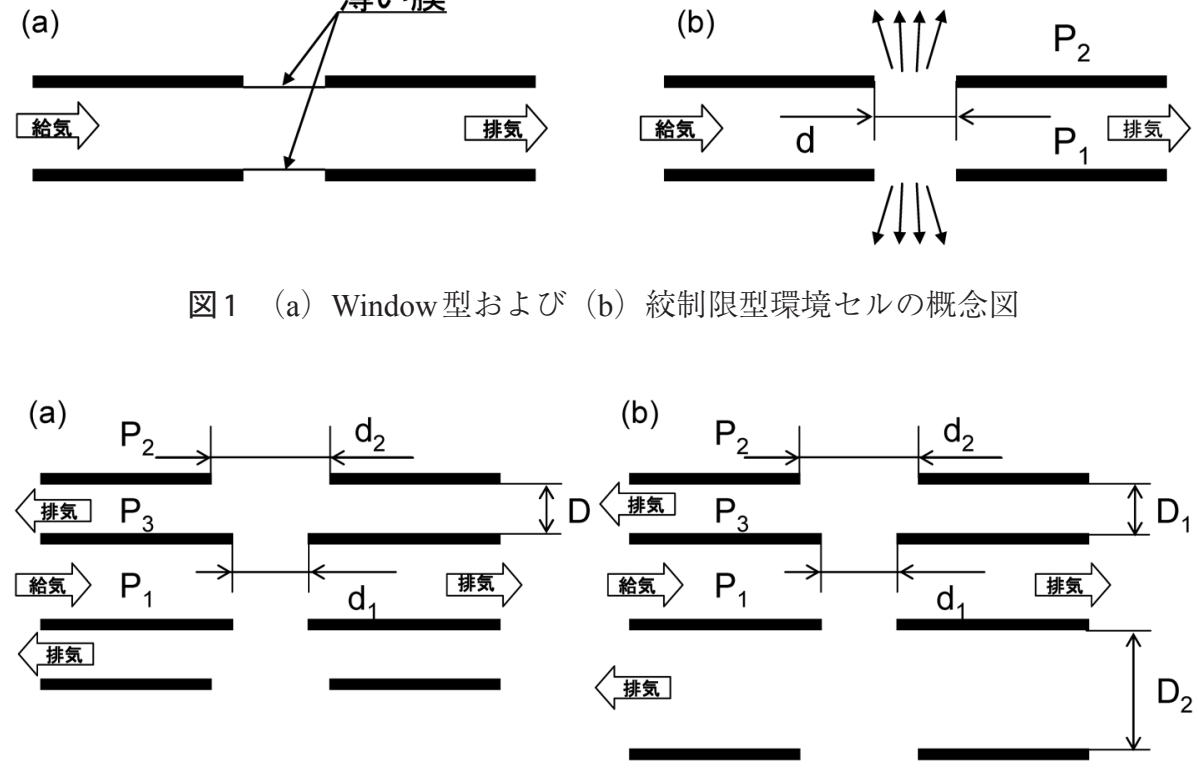

図 2 差動排気型環境セルの概念図。二次絞が（a）対称配置，（b）非対称配置の場合

験装置は, 1960 年代後半から，1970年代に開発された ${ }^{7)}$ 。環 境セルは，図1に概念的に示すようにWindow型と絞制限型 に分類される。この分類の名称には, Window型に対してク ローズドタイプ，壁膜型，隔膜型，絞制限型に対してはオー プンタイプ, ダイナミックバキュームタイプ, 開放型などさ まざまな呼び方があるが，本稿では参考文献7）に従う。

\section{1 Window型環境セル}

Window型とは，試料上下に電子線を透過できる薄い膜で できたWindowを置き，その間にガス雾囲気を閉じ込める夕 イプである。このため, ガスはWindowによって完全にシー ルされ，顕微鏡の真空を乱さない。一方，Windowの材質に は，鏡体中の真空と環境セル内の雲囲気ガスとの圧力差に耐 える強度と同時に, 十分な電子線を透過させる薄さが要求さ れる。試料加熱や電子線誘起化学反応は, 膜を破壊する危険 性がある。

膜の作製方法にはさまざまな工夫が行われており, 現在も よく使用されているものとしては, カーボン/コロジオン/シ リカの三層膜 ${ }^{10)}$ や，蒸着分子速度を制御したカーボン膜 ${ }^{11)}$ などがある。特殊なものではイオンミリングしたアルミナ単 結晶膜を使って $3 \mathrm{~atm}$ まで耐えられる膜が作製された例があ る ${ }^{12)}$ 。特に，近年ではMEMS 技術を用いて Si チップ上に窒 化けい素膜を形成したもの ${ }^{13)}{ }^{14)}$ が高い膜の安定性を示して いる。特に試料を完全に封じ达め，観察中にガスを供給しな

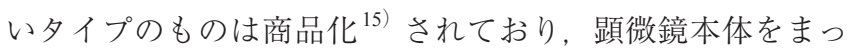
たく改造せずに済むため普及しつつある。

\section{2 絞制限型環境セル}

絞制限型環境セルは, 試料上下にひとつ, あるいは複数の 穴の開いた絞りを置き，試料周辺から鏡体中へのガスのリー クを制限する。このため, 絞りの径がセルの能力を決める上 で非常に重要である。Window型と異なり，精密な真空系の 設計が要求されるが, より高い分解能および自由度が得られ る。
絞りを通してのガス流の性質は, セル中の圧力により分子 流あるいは粘性流となる。分子流領域となる数 $100 \mathrm{~Pa}$ 以下の 圧力においては, ガス分子の平均自由行程は, セルや絞り径 と比べて十分大きく, 分子間の衝突はまれなのでお互いの運 動を邪魔しない。分子流領域の上限近傍の圧力において, 例 えば $20^{\circ} \mathrm{C}$ 空気では, セル圧が $130 \mathrm{~Pa}$ の場合, 平均自由行 程は約 $50 \mu \mathrm{m}$ であり, 絞りサイズと同程度でセルの大きさよ り十分小さい。セル中の圧力が増すと, 分子間の衝突の平均 自由行程は減少し, 分子流から粘性流への変化が起きる。こ の変化が起きるセル圧は明確ではなく，2つの圧力範囲の間 に中間領域が存在する。さらに高い圧力では, 絞りを通り抜 けるガスの速度は音速となり, ガス流量はガス分子の最大速 度（つまり温度）によってのみ制限される。

上記のような気体の特性を考慮して実際の環境セルの特性 を検討すると, 単一絞りを用いると圧力範囲が非常に制限さ れる。ある程度の余裕を持って実用的なセル内の圧力を得る には，とてつもなく小さく，結果として軸合せが困難で，厳 しい視野制限をもたらす絞りが必要となる。そこで，一次絞 に直列に二次絞を入れ，一次絞と二次絞の間に補助的な真空 系を接続し排気する差動排気システムが考案された ${ }^{16)}$ 。

このシステムでは, 顕微鏡の鏡体と差動排気された容器 間の圧力差があまり大きくないため, 一次絞を許容可能な サイズ (通常 $100 \mu \mathrm{m}$ 程度) にし，二次絞をさらに大きくす ることができる。この構造を模式的にに示すと図2 $2 \mathrm{a}$ のう になり, 二次絞を通じての最終リークレートは, $P_{1}$ (環境セ ルチャンバ圧), $P_{3}$ (差動排気チャンバ圧), $d_{1}$ (一次絞径), $d_{2}$ (二次絞径),$D$ (一次・二次絞間隔) および絞近傍の差動 排気速度と顕微鏡の有効排気速度で決まる。一次と二次の絞 間隔 $D$ は, ポールピースのギャップ間隔が上限となる。また, あまり大きな $D$ 值は, 電子線の散乱の視点からも, 正確な軸 合せの点からも好ましくない。一方，Dの下限は一次絞から のガス流が二次絞を直接通り抜け, 差動排気チャンバが有効 


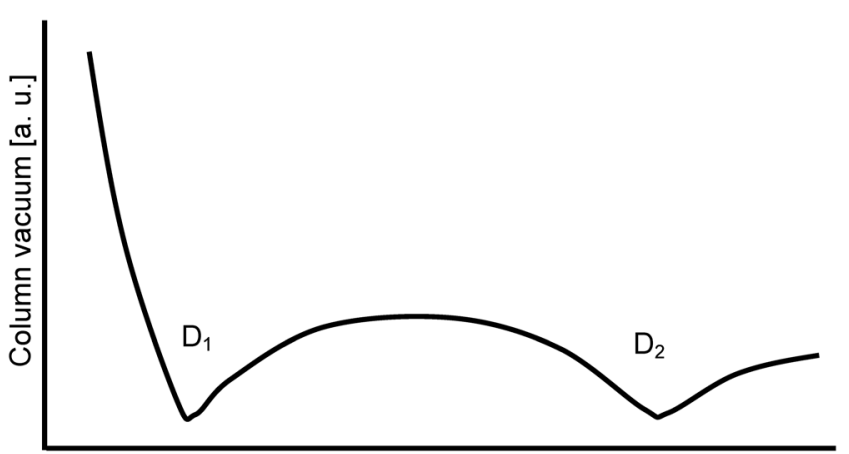

Distance between $1^{\text {st }}$ and $2^{\text {nd }}$ aperture (D) [a. u.]

図 3 一次絞と同サイズの二次絞の $D$ と鏡体圧の関係

でなくなる值である。計算によって求められたこれらの変数 を用いて，特別に設計されたリグ中で様々な構造のセルにつ いて検証が行われた結果 ${ }^{17)}, D$ と鏡体圧 $P_{2}$ の関係は一般的 に図3のようになり，Dには鏡体圧 $P_{2}$ が最小になる $D_{1}$ と $D_{2}$ があることがわかった。最初に $P_{2}$ が最小となる $D_{1}$ は，一次 絞からのガス流が二次絞でさえぎられるために起きる。 $D_{2}$ で $P_{2}$ の最小值は, 差動排気チャンバが大きくなるため, 排 気のコンダクタンスが大きくなることによる。 $D_{1}$ と $D_{1} に お$ ける $P_{2}$ の最小圧は一次絞サイズ $d_{1}$ に依存するが, 二次絞サ イズ $d_{2}$ には依存しない。一方，絞サイズを一定に保ち，差 動排気チャンバの圧力 $P_{3}$ を高くすると, $D_{1}$ での $P_{2}$ の最小圧 は増加し， $D_{1}$ は小さくなるという性質がある。

鏡体の真空度を最小にする $D$ が2つ存在するということ は，一方を $D_{2}$ とする非対称な高さのセルとすることにより， 作動排気チャンバ中でのガスによる電子の散乱をそれほど大 きくせずに作動排気のコンダクタンスを増加させ, 空間的余

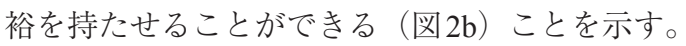

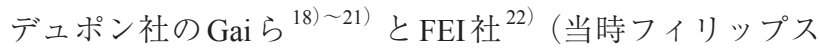
社）は，対物レンズポールピースに差動排気のための排気ラ インの穴を開け，一次および二次絞をポールピース内に取付 けることにより試料室全体を環境七ルとし，さまざまなタイ プの試料ホルダが使用できる絞制限型環境電子顕微鏡を開発 した。このタイプの環境電子顕微鏡を用いて, 大阪大学の竹 田らはカーボンナノチューブの成長過程を原子レベルで観察 し，非常に美しい成果を発表している ${ }^{23) ~ 27) ~}$

Window型環境セル, 絞制限型環境セルのどちらも, 近年, 最新型の高分解能透過電子顕微鏡で使用可能な夕イプのもの が市販化されてきており, さまざまなレベルのユーザーが, さまざまな対象へ応用する機運が高まってきている。今後, その場観察や環境電子顕微鏡による研究を検討している方々 の一助となればと思い，以下に筆者らがかかわったその場観 察のいくつかの例を紹介する。

\section{3. 真空中その場加熱実験 ${ }^{28)}$}

一般的に, 透過電子顕微鏡用試料は $3 \mathrm{~mm}$ のディスク状に 加工される。市販されている伝熱型試料加熱ホルダは, こ の $3 \mathrm{~mm}$ の試料を取付けることができる小型炉を持ち，特に $800^{\circ} \mathrm{C}$ 以上に加熱される場合は, 周辺の部品の過熱やドリフ

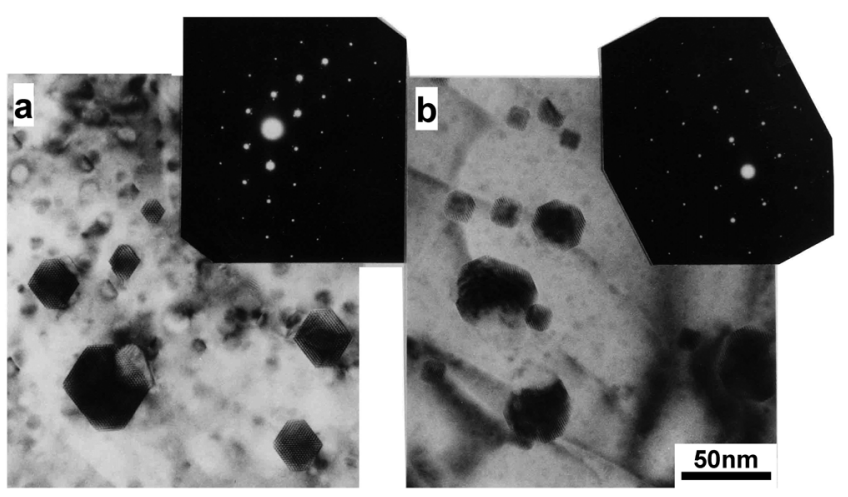

図 4 液体急冷法で作製した Al-In合金の典型的な組 織。(a)〈110〉および (b) 〈100〉より観察した 透過電子顕微鏡像。それぞれの挿図は，対応する 電子線回折パターンを示す29)

卜を低減するために炉の周囲が水冷される。しかし，このよ うなタイプのホルダは, 設定した温度で安定させるためには $1 \sim 2$ 時間を要し, 加熱温度の上限も $1000 \sim 1300^{\circ} \mathrm{C}$ に限定さ れる。

\section{$3.1 \ln$ の固・液界面}

試料の熱ドリフトの問題を回避するために, 我々は, 試料 の変化が観察される温度範囲が狭い融解現象を選択した。ま た，変化に伴う試料形状の変化によるドリフトを抑えるため に，対象試料を熱的に安定なマトリックス中に埋込む工夫を 行ったところ，これまで非常に不安定で捉えることが困難で あった固・液界面を原子レベルで観察することに成功した。 試料加熱過程において, まず試料を融点直下 $2 \sim 3^{\circ} \mathrm{C}$ まで加 熱し，熱ドリフトが止まるまで待つ。その後，ごくわずかの 温度上昇を電子線の照射密度を上げ, ビームヒーティングに より行い, 融解現象を開始させるという手法を用いた。この ような工夫のもと, $\mathrm{Al}$ マトリックスに埋込まれた In粒子の 融解過程を H-1250ST 超高圧電子顕微鏡を用い連続的にその 場観察した ${ }^{29), 30)}$

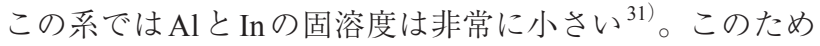
液体急冷法で作製した Al-In合金試料は図4に示すように, In 粒子が $\mathrm{Al}$ マトリックス中に均一に分散している典型的な 組織を示す。In粒子の形状は $\mathrm{Al}$ マトリックスと Inの格子間 のモアレ縞により, 容易に判別できる。結晶性のIn粒子は 接頭八面体をしており，8つの $\{111\}_{\mathrm{Al} \text { In }}$ と 6つの $\{100\}_{\mathrm{Al}, \mathrm{In}}$ 晶癖面で囲まれている。

融解は, いずれかの $\{100\}$ 面から始まり, In粒子内部へ 向かって進む。図 5 は, In 粒子中の固 - 液界面の高分解能観 察例を示す。Inの固・液界面と固体 $\mathrm{Al}$ と液体 In 間の固・液 界面間の接触角を, 図中点線で示すように直接測定すること ができ, ナノサイズの粒子の熱力学を論じることが可能と なった ${ }^{30), 32)}$ 。融解過程で, 部分融解したIn粒子中に形成さ れた $\{110\}$ と $\{100\}$ 固・液界面を, 図6aおよびbにそれぞ れ示すように, エッジオン方向から観察することができた。 固・液界面は原子レベルではシャープではないことがわか る。モアレ縞の強度変化から決定した固・液界面の厚さは, Temikinの理論 ${ }^{33)}$ から求められる結果によく対応していた。 


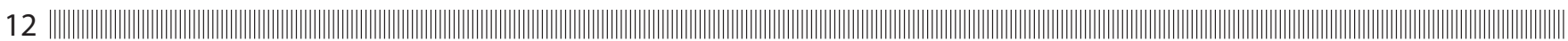

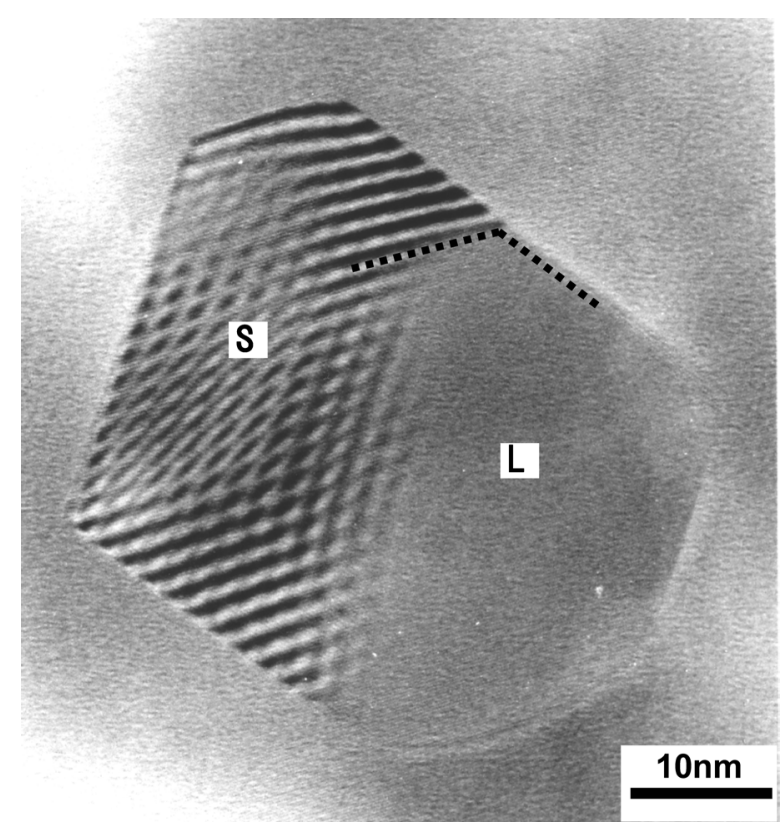

図5 In 粒子中の固・液界面高分解能観察例 ${ }^{29)}$

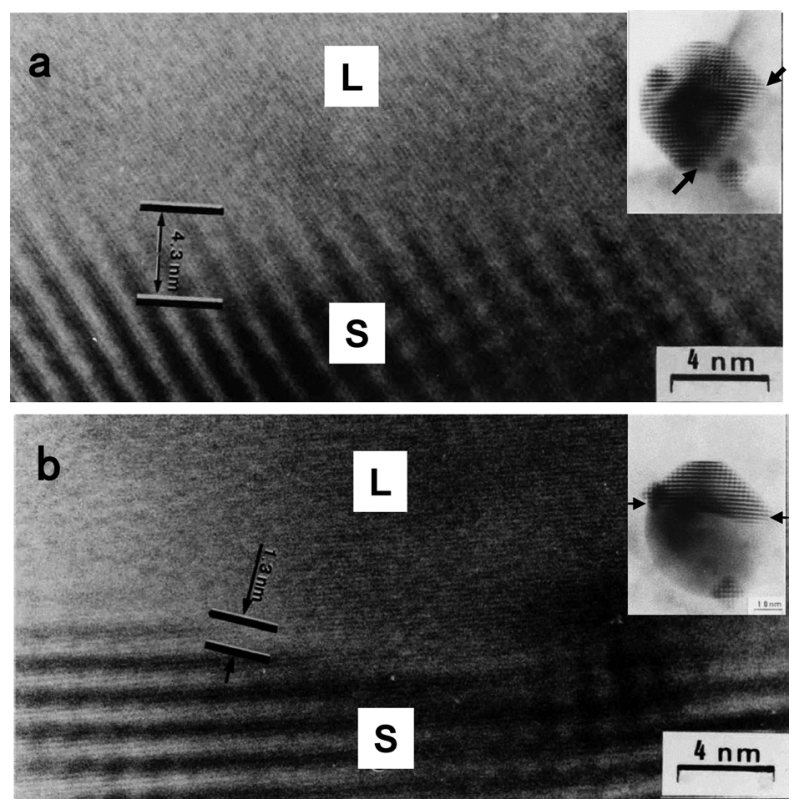

図6 In粒子中に形成された（a）\{110\}と（b）\{100\} 固・ 液界面。挿図は，それぞれの固・液界面が観察さ れたIn粒子の全体像を示す

我々の結果に続き， $\mathrm{Bi}-\mathrm{Al}^{34)}, \mathrm{Pb}-\mathrm{Al}^{35)}$ 38)， $\mathrm{Pb}-\mathrm{Sn}-\mathrm{Al}^{39)}$ 合 金に関する結果が報告され，熱力学的解析も報告されてい $3^{30), 40), 41)}$ 。

\section{2 より高温・高分解能での観察 ${ }^{28}$}

触媒研究者やその他からの要求に沿うため, 従来型透過 電子顕微鏡で使用できる粉末試料用加熱ホルダが開発され た ${ }^{9)}$ 。耐熱金属，例えばWのワイヤ $(\sim \phi 25 \mu \mathrm{m})$ を螺旋状に 巻いたものを加熱体に用い, 加熱ヒータの電源としては, 電 池からの電流を用いている。電池からの電流は, 透過電子顕 微鏡像を乱すいかなる変動や不安定性を持たないため大変有

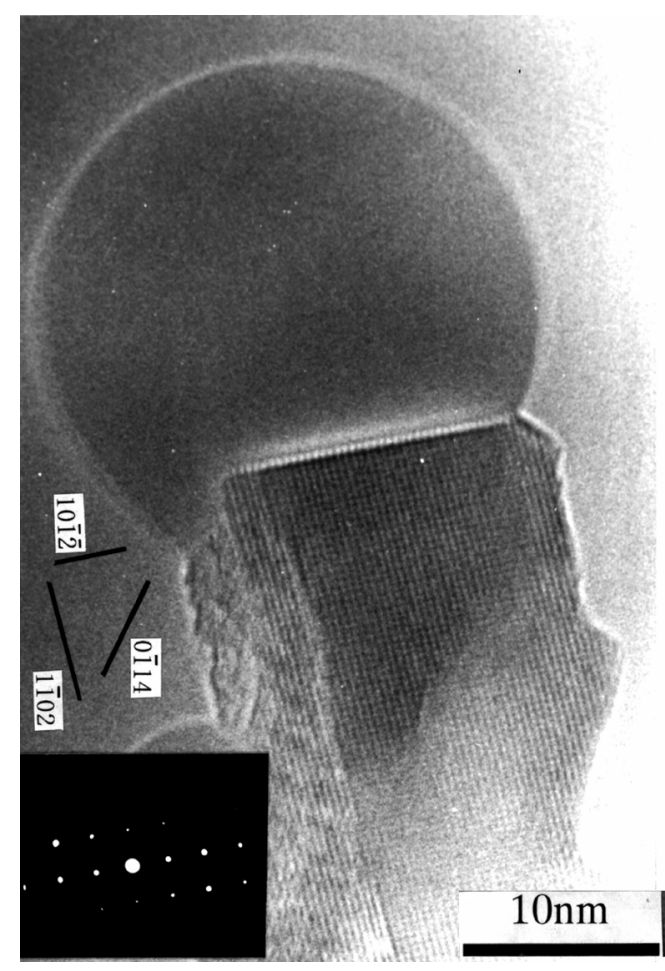

図７液滴の下から成長したアルミナのウイスカ。挿図は ウイスカ部分から得られた電子線回折パターン42)

効であり, 2 個の UM-1 $(1.5 \mathrm{~V})$ の電池で, $\phi 25 \mu \mathrm{m}$ の Wヒー 夕を $1500^{\circ} \mathrm{C} に 10$ 時間も保つことができる。粉末試料は加熱 体に直接載せて使用される。

この試料ホルダの大きな利点は, 非常に小さい熱容量であ る。これはその場加熱実験にはとても有利な点である。第一 に，加熱時に試料ドリフトが非常に小さいということであ る。この結果, $1000^{\circ} \mathrm{C}$ を超える温度で従来型透過電子顕微 鏡のフィルムに高分解能像を記録できるようになった。第二 に, 水冷機構が必要ではない点である。第三に, 試料ホルダ の厚さは $2 \mathrm{~mm}$ 程度で, 高分解の対物レンズのポールピース 間に挿入できる点である。

その他の利点は，加熱体が容易に交換でき，交換コストが 従来の加熱ホルダに対して非常に低い点である。これは, 超 高温のその場加熱実験をしばしば行う者にとって, 非常に重 要である。加熱温度と加熱電流の関係は, 赤外線温度計によ る測定でおおよそ補正された後, サイズ効果により融点が変 化しない程度に十分大きい金属箔の融解を観察することに より, より精密に校正される。下記は, このホルダを用い て行われた結果である。観察には, H-9000NARを加速電圧 $300 \mathrm{kV}$ で用いた。

\section{2 .1 固 · 液反応}

より高温での一般的な観察例として，アルミナの固・液界 面の観察を簡単に示す ${ }^{42)}$ 。 $2000^{\circ} \mathrm{C}$ において半球状の液滴が, 表面に形成される。これらの液滴は直径を増し， $50 \mathrm{~nm}$ に達 するとそれぞれの液滴の下からアルミナのウィスカが成長し

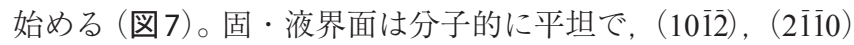
および $(1 \overline{1} 0 \overline{2})$ 晶癖面を持つ。

図8はアルミナウィスカと液滴間の固・液界面での核生成 


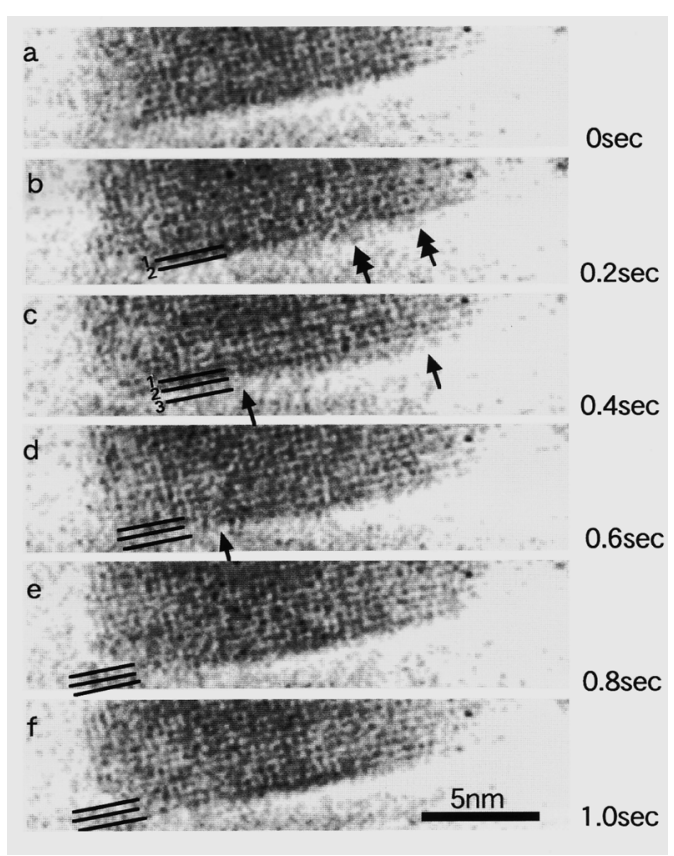

図8アルミナウィスカと液滴間の固・液界面での核生 成を示す一連のビデオ画像 ${ }^{42}$

を示す一連のビデオ画像である。図中上部の格子縞が見られ る部分がアルミナ結晶相で下部が液相である。図8aに示す ように固・液界面は初め平坦で, 線 1 2が示す格子が固相 の最上層であったが,この固・液界面に図8bの二重矢印で 示す範囲に一分子層の雲のようなコントラストが形成され始 める。これは新しいアルミナ結晶の一分子層の核に相当する と思われる。この層は図 $8 \mathrm{c}$ の線 2 3に示すように, 線 1２ に示す本来の格子間隔より幅が広いことがわかる。その後, 固・液界面上で図 $8 \mathrm{c}, \mathrm{d}$ 中の矢印の範囲に示すように横方向

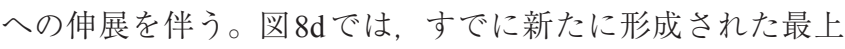
層の右端は視野外に移動してしまっている。伸展過程中に, この最上層の厚さは本来の格子間隔に等しくなり, 固・液界 面に垂直にアルミナウィスカ側の格子に対応した格子縞の形 成が見られた。核は両サイドに新しい格子を加えながら進展 を続け，固・液界面全体を新しい一分子層で覆った（図 $8 \mathrm{e}$, f)。さらに詳細なアルミナ固・液界面の挙動は参考文献 43) を参照してもらいたい。

\subsection{2 $\mathrm{Al}-\mathrm{Si}$ 合金中の固・液界面}

固体 $\mathrm{Si}$ と液体 $\mathrm{Al}$ 間の固・液界面と $\mathrm{Si}$ の表面での再構成を 観察した。図9に示すように $\mathrm{Al}$ と $\mathrm{Si}$ 粉末を混合したものを, 加熱実験中に融合させた。この試料を再加熱し, 融解・凝固 過程に扮ける, Al-Si固・液界面の原子構造と挙動を図10の ように観察した $\left.{ }^{44)}, 45\right)$ 。固体 $\mathrm{Si}$ の [110] 方向から観察した固・ 液界面は， $\{111\}$ 面に明確な晶癖面を持っており, 最上層の 原子層は，マトリックス中の $60 \%$ のコントラストを持って いた。マルチスライス法を用いた界面のイメージシミュレー ション ${ }^{46)}$ と実験像のマッチングは, 結晶表面と液体間に, 一または二層の $\mathrm{Si}$ が部分的に凝固した遷移層があることを 示した ${ }^{45)}$ 。また, $\mathrm{Al}$ が $660^{\circ} \mathrm{C} て ゙$ 融解すると, 固体 $\mathrm{Si}$ と液体 $\mathrm{Al}$ 界面は原子的に平坦になり（図11a），Alが凝固すると固

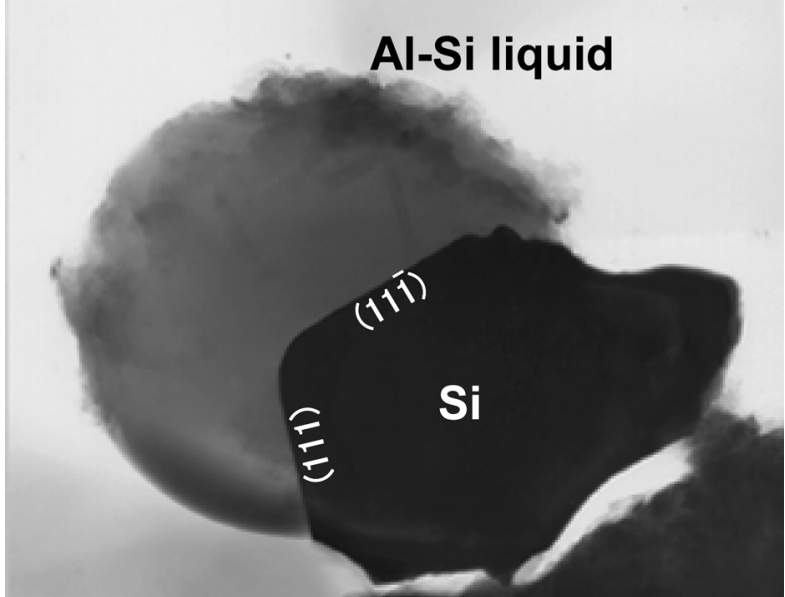

図9 $\mathrm{Al}$ と Si粉末を混合したものを，加熱実験中に融合 させたもの ${ }^{44)}$

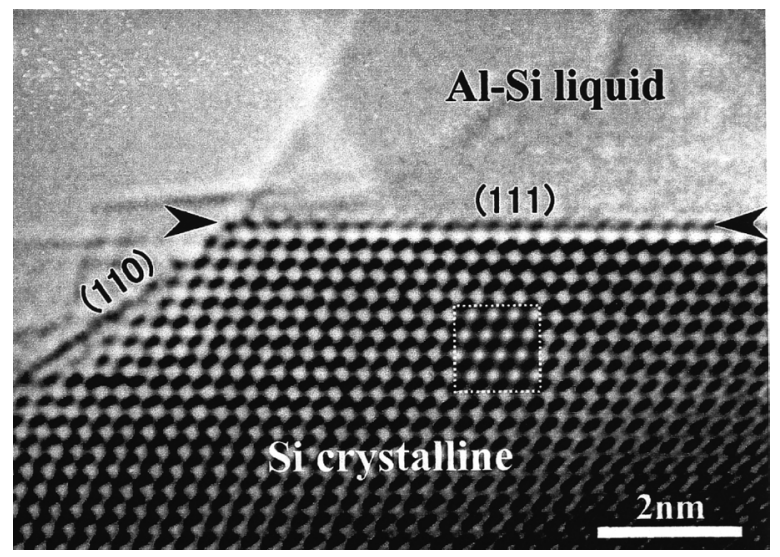

図 $10 \mathrm{Al}-\mathrm{Si}$ 固・液界面の高分解能像

体 $\mathrm{Al}$ と固体 $\mathrm{Si}$ 界面は図 $11 \mathrm{~b}$ に示すようにラフになる。この $\mathrm{Al} / \mathrm{Si}$ 界面の変化には, 明確な再現性があった。

一方, 図 $11 \mathrm{c}$ は図 $11 \mathrm{a}, \mathrm{b}$ とは別の領域の像であるが, 厚い $\mathrm{Al}$ 液相に覆われていない $\mathrm{Si}$ 表面も原子レベルで非常に平坦 で晶癖面を示している。このような平坦な $\mathrm{Si}$ 表面は, 融解 した $\mathrm{Al}$ の液相が $1 \mathrm{ML}$ 程度 $\mathrm{Si}$ 表面をぬらした場合のみに見ら

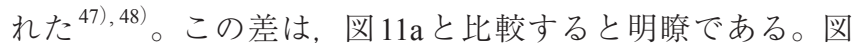
$11 \mathrm{a}$ では $\mathrm{Al}$ 液相は $\mathrm{Si}$ の右側面の久覆っており, 図上側に向い ている $\mathrm{Si}$ 表面は薄い表面層（おそらくは酸化層）が覆って おり, 晶癖面が見られない。しかし, 図 $11 \mathrm{c} て ゙ は \mathrm{Al}$ 液相が右 側面からはみ出し, 図上側を向いた $\mathrm{Si}$ 表面の一部を覆って おり，それ以外の部分では高分解能電子顕微鏡像上では明 確な表面層が観察されない。図11cのような $\mathrm{Si}$ 表面も, その 後 $\mathrm{Al}$ が再凝固すると, 酸化層と思われる表面層で覆われて 平坦な晶癖面を消失し図 $11 \mathrm{~b}$ 同様なラフな表面を示した。こ のような現象は, 薄い $\mathrm{Al}$ 液相で覆われた $\mathrm{Si}$ 表面で再構成が 起きているためと考えられる。 $\mathrm{Si}$ 表面の再構成は超高真空中 でよく観察されるが, このように $\mathrm{Al}$ 液相でぬれた後に起き る特徵的な $\mathrm{Si}$ 表面再構成が, 通常の鏡体中の真空度である $10^{-5} \mathrm{~Pa}$ という真空度でも起きることが示された。同様な現象 


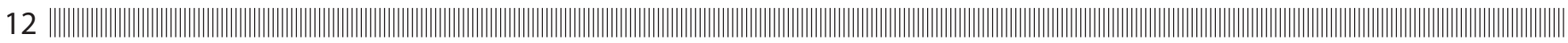
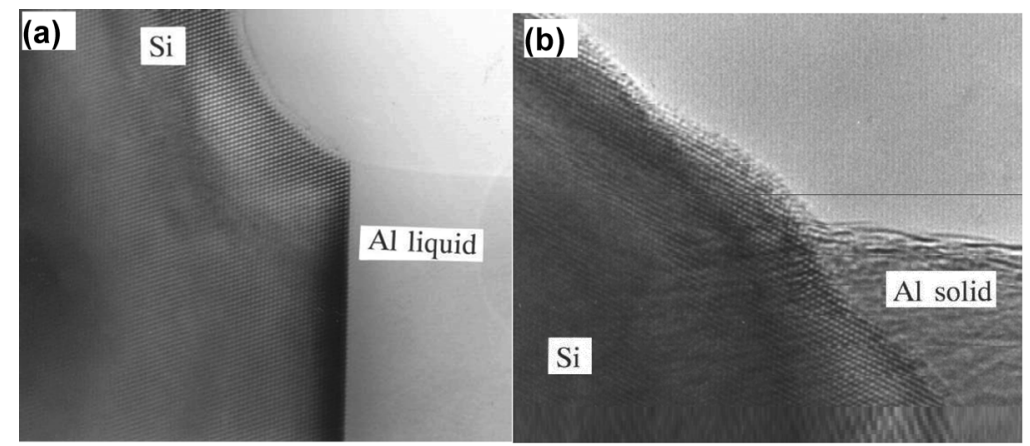

(c)

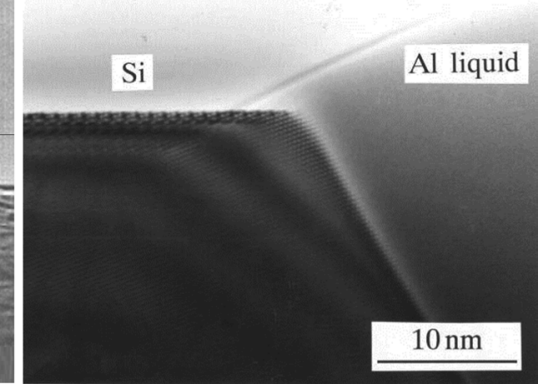

図 $11 \mathrm{Al} / \mathrm{Si}$ 界面の変化。（a）原子的に平坦な固体 $\mathrm{Si}$ と液体 $\mathrm{Al}$ 界面，（b）ラフな形状を示す固体 $\mathrm{Al}$ と固体 $\mathrm{Si}$ 界面，(c) $\mathrm{Al}$ が融解すると, 原子的に明確な晶癖面を示す $\mathrm{Si}$ の表面 ${ }^{48}$

が $\mathrm{Si}$ 上に $\mathrm{Au}$ を蒸着した試料でも観察されている ${ }^{49)} 。$

\section{4. 反応科学超高圧電子顕微鏡}

上記のように，われわれは真空中での高分解能その場加熱 実験を試みてきたが，同様な現象あるいは触媒反応のような 積極的なガス雾囲気での現象を，高温その場観察したいとい う要求が増えてきた。上記の上野-坂ホルダにガス導入機構 を追加したホルダによる，超高温におけるその場観察実験の 報告 ${ }^{50)}$ や，すでに紹介したFEI社の環境電子顕微鏡を用い

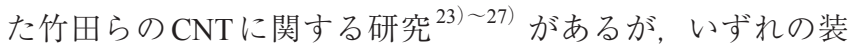
置も環境セ儿特有のさまざまな制限が課せられた条件下での 研究である。そこで, 我々を含む名古屋大学の電子顕微鏡グ ループでは, 従来の電子顕微鏡の高度な機能を制限すること なく，大気圧に近いレベルのガス雲囲気下でのその場実験が できる装置を実現するために, 新規開発超高圧電子顕微鏡の ために, 観察中に電子線通路に絞制限型環境七ルを出し入れ できる機構を開発した ${ }^{51)}$ 。これにより，ガス雾囲気下での 観察前後では完全に環境セルを取り除き，視野や回折角の制 限なく観察することができ, 詳細な観察後に, 試料を大気に 曝すことなくガス䨌囲気中観察を行うことができるように なった。また，さらにガス交換中にある程度排気した後，わ ずかに可動式環境セルを後退させることで，残留ガスを鏡体 側の大容量の真空系へ開放することにより短時間で排気し, 10 分程度の短時間で環境ガスを入れ替えることができる能 力を持たせることができるようになった。

われわれは，上記の環境セル中で，上野一坂ホルダの試料 固定法に次のような改良を加えることにより，より応用範囲 を広げる研究を行っている。

\section{1 断面その場観察}

材料とガス雾囲気の反応は，表面で起きる。反応生成物が 固体である場合は，表面に蓄積する。表面に蓄積した反応生 成物は層状構造を作り, 材料表面の性質を変えたり, その後 の表面反応の進展を左右したりする。ほとんどの場合，この ような表面層の構造は, 反応を停止させた後に断面試料を作 製し解析されている。このような手法は, 反応停止過程でさ まざまな本来の反応過程を乱す現象が入り込む余地を作って しまう。試料処理過程などによる測定しようとしている現象 への事後の外的な力による緩和の影響を回避できるその場観 察手法は, この問題の解決には打って付けの方法である。し

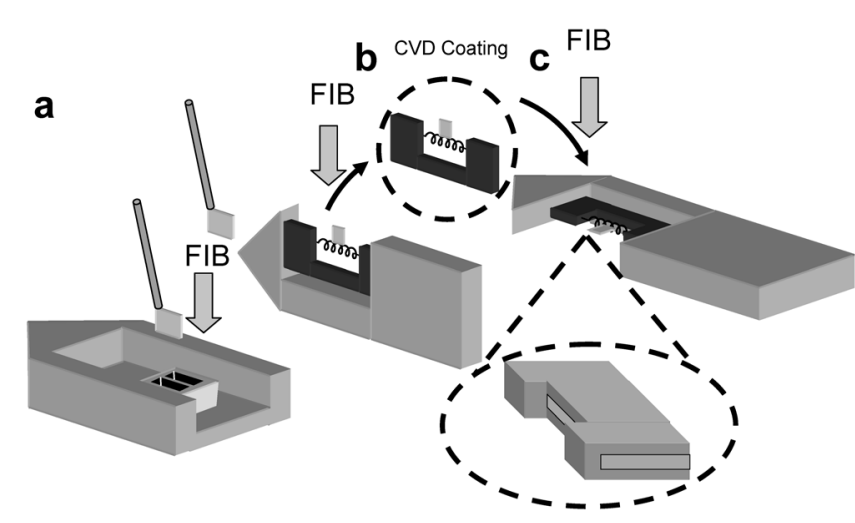

図 12 断面その場透過電子顕微鏡観察用試料作製手 順。(a) フィラメントカセットへのマイクロサ ンプリング, (b) フィラメントカセットを取出 しプラズマCVD重合膜コーティングを行う，(c) 再度, 集束イオンビーム加工機に入れ，表面保 護膜の一部を取り除く

かし, 従来の方法では, 変化している表面現象を断面方向か らその場観察することができなかった。そこで, 断面透過電 子顕微鏡試料の側面のみを, ガス雲囲気に不活性で, ガスの 侵入を効果的に抑制でき, しかも電子線透過能の高い保護膜 で覆い, 表面反応を断面方向から観察する手法を以下のよう

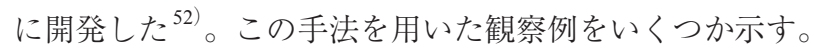

断面その場透過電子顕微鏡観察用試料は, マイクロサンプ リング機能を有する, 集束イオンビーム加工装置 (HITACHI FB-2000）を用いて作製した。図12aに示すように，集束イ オンビーム加工装置で薄片状に加工した試料を, マイクロサ ンプリング用針にWデポジションにより接着し, 試料本来 の表面側を上方に維持しながら取り上げた。W製加熱フィラ メントをU字形銅プレート上に固定したもの（フィラメント カセット) ${ }^{53)}$ を, 集束イオンビーム加工装置用フィラメント カセット専用試料ホルダ (Enomoto A\&V FIB Holder : 以下, 専用ホルダとする）に，加熱フィラメントが上側になるよう に取り付け，集束イオンビーム加工装置中に挿入した。マイ クロサンプリングされた薄片状試料を, フィラメントカセッ トの加熱フィラメント上に, 試料本来の表面側を上方に維持 しながらWデポジションにより固定した後, サンプリング 針を切り離し, 電子線透過可能な厚さまで加工した。試料を 

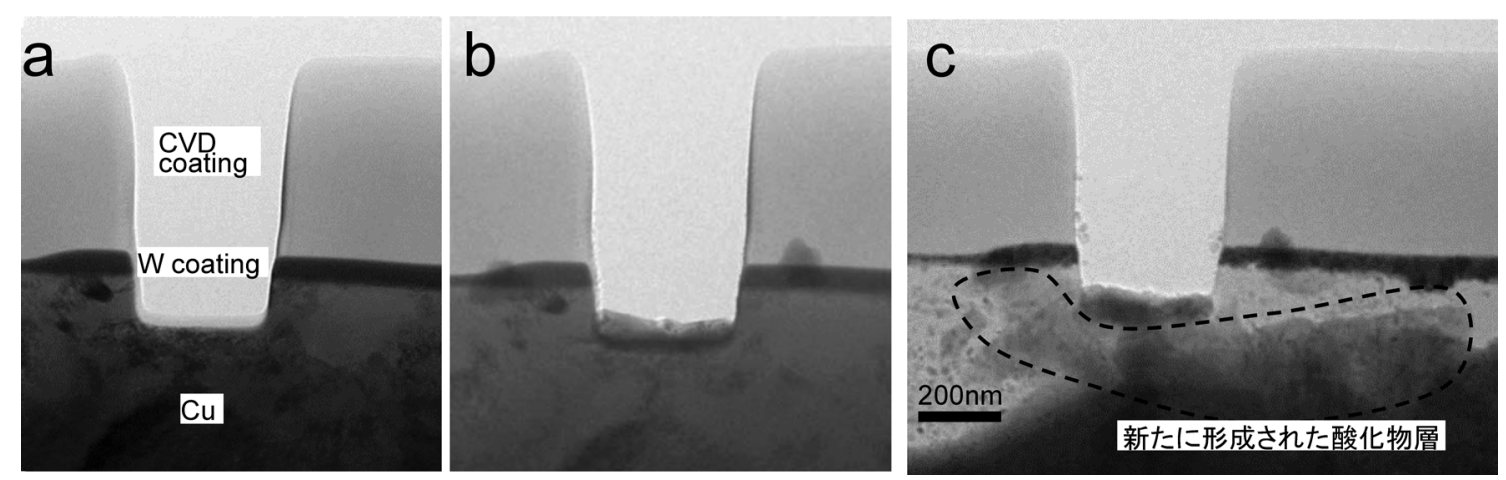

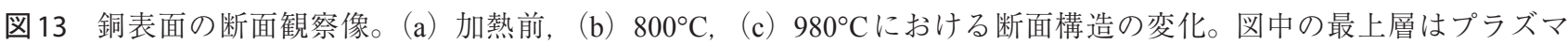
CVD 重合膜，中間の黒い層は集束イオンビーム加工時の表面保護 $\mathrm{W}$ 層，最下層が銅に対応する。（c）の点線で囲 まれた部分は新たに形成された酸化物層

固定したフィラメントカセットは，図 $12 \mathrm{~b} に$ 示すように，専 用試料ホルダより取りはずし，CVDコーティング装置に移 L, $\mathrm{CH}_{4}: \mathrm{C}_{2} \mathrm{H}_{4}$ 比 $1: 3$, ガス圧 $3 \mathrm{~Pa}$ の条件で, 全面をプラズマ CVD重合膜でコートし，表面保護層とした。その後，専用 ホルダに，試料を固定したフィラメントカセットを再度取付 け，試料薄膜を水平にした状態で，試料本来の表面側のエッ ジに存在するプラズマCVD重合膜を集束イオンビーム加工 により取り除き，試料本来の表面を露出させた（図 12c）。 上記の手順により，薄膜化された断面試料の側面はプラズ マCVD重合膜に覆われ, 試料本来の表面のみが真空中に露 出した試料を作製した。加工の終わったフィラメントカセッ トの両側の電極を，二電極式上野-坂ホルダ上のそれぞれの 電極にねじ止めした後, U字形銅プレートの底部をマイクロ ニッパーを用いて切り離し, 加熱フィラメントのみに電流が 流れるようにした。このような手法で試料を作製し，銅表面 の酸化過程および $\mathrm{Nb}-\mathrm{Pd}$ 系水素透過膜の劣化過程を名古屋 大学反応科学超高圧電子顕微鏡で観察した例を紹介する。

\section{1.1 銅表面}

材料, 特に金属材料の表面の酸化過程は, 材料の加工およ び使用に大きな影響を及ぼす。一般的な金属の代表として銅 表面の酸化雰囲気中での高温挙動を観察した ${ }^{54)}$

酸素ガスを導入しながら電子顕微鏡中の䨌囲気を 3 $\times 10^{-4} \mathrm{~Pa}$ に保ち観察を行った。観察した試料部分は，全体が 1つの結晶で構成されていた。図13aに示すように，集束イ オンビーム加工機で切り取られた表面には常温では何も存在 しないが，試料を $800^{\circ} \mathrm{C}$ まで加熱すると，図 $13 \mathrm{~b}$ に示すよう に酸素䨌囲気に暴露された試料表面に酸化物と思われる微細 な結晶が形成された。温度を上げるに従ってごくわずかに厚 みを増したが, 試料内部への進展はわずかであった。試料が $980^{\circ} \mathrm{C}$ まで加熱されると, 図 $13 \mathrm{c} に$ に示されるように酸化膜と 考えられる層の左右から Cavityが形成され，急激に進展して いった。 $\mathrm{Cu}$ 部分では等厚干渉縞が観察され, 融解していな いことが確認されるため, この現象は表面酸化膜と考えられ る層の薄い部分が破壊され， $\mathrm{Cu}$ が昇華していっているので はないかと考えられる。同様の現象は，炭化したゼラチン膜 で覆われた $\mathrm{Cu}$ 粒子でもほぼ同じ温度で観察されている ${ }^{55)} 。$ 保護膜に覆われた試料は徐々になくなると同時に, 新たに現
れた表面で酸化と思われる現象が進行し, 図 $13 \mathrm{c}$ の点線の枠 で示されるような酸化物と思われる結晶が成長した。また, 加熱温度 $980^{\circ} \mathrm{C}$ においても, 表面保護層はほとんどダメージ を受けず試料を覆っていることがわかり，プラズマCVD重 合膜が酸素ガスに対して $1000^{\circ} \mathrm{C}$ 近い温度でも有効であるこ とがわかる。

\section{4. $1.2 \mathrm{Pd}-\mathrm{Nb}$ 水素透過膜}

近年, 従来の $\mathrm{Pd}$ 基合金水素透過膜に代わる, より安価な 金属水素透過膜の開発が求められている ${ }^{56)}$ 。最も有望な候 補として，V, Nb，Taなどのより安価な 5 族金属の表面にPdを 被覆した，複合金属膜が検討されている ${ }^{57)}$ 。しかし，使用 時の高温における透過能の劣化という問題がある ${ }^{58)}$ 。透過 能の劣化は高温ほど激しく起こることから，金属層間の相互 拡散を指摘する報告があるが58),59)，一方で，基材の 5 族金 属の酸化を引き起こすと考えられる, Pd膜表面の穿孔劣化 現象を指摘する報告がある ${ }^{60)}$ 。しかし, 表面 Pd膜の構造変 化や，基材金属との内部拡散に関する，詳細な解析は行われ ていない。もし，透過能の劣化の原因が内部拡散だとしても， 主な原因が透過能の低い金属間化合物層の形成なのか, 界面 への非金属不純物の析出によるのかは, 明らかになっていな $\omega^{58)}$ 。そこで, $\mathrm{Pd}$ 被覆 $\mathrm{Nb}$ 水素透過膜の微細構造の変化過程 を，断面その場透過電子顕微鏡観察法を用いて観察し， Pd 膜表面の穿孔形成過程の解析を試みた ${ }^{61), 62) 。 ~}$

試料には， $99.96 \mathrm{mass} \%$ の純 $\mathrm{Nb}$ 試料を $12 \mathrm{~mm}$ 径 $0.5 \mathrm{~mm}$ 厚さ のディスク状に整形した物を用いた。整形した試料の表面を 機械研磨した後，両表面に200nm厚さのPdを参考文献 63） に示す方法でコーティングした。準備した試料を，上記 4.1 節で述べた断面その場観察用試料 ${ }^{53)} に$ 加工した。

図 14 に, $\mathrm{Pd}$ 被覆 $\mathrm{Nb}$ 水素透過膜の断面透過電子顕微鏡像 を示す。図上方が, 透過膜本来の表面側である。表面から 約 $200 \mathrm{~nm}$ 程度の厚さの Pd層が観察される。Pd層は, 膜面垂 直方向に伸びた結晶が多く存在する, 不完全な柱状晶構造 をしている。Pd層の下には，膜面に平行方向に伸びた 200〜 $300 \mathrm{~nm}$ の粒サイズを持つ $\mathrm{Nb}$ の細粒層が存在し, さらにその 下には， $\mu \mathrm{m}$ 台の粒サイズを持つ $\mathrm{Nb}$ 層が存在することがわか る。

フィラメントカセットの加熱フィラメント上に固定され 


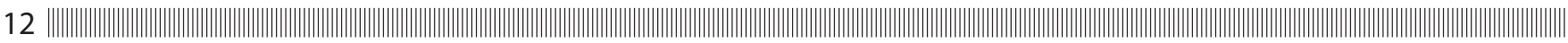

た，図14に示したような断面試料を，プラズマCVD重合膜 でコートし，試料本来の表面側，つまり，図上方の試料エッ ジ部分のプラズマCVD重合膜を取り除いたものを，透過電 子顕微鏡中でその場加熱観察した結果を，図15に示す。

図15aに加熱前の断面試料の明視野像を示す。図 14 と同様 な, 柱状晶様のPd層が観察されている。加熱フィラメント に電流を流し， $500^{\circ} \mathrm{C}$ まで加熱すると，図 $15 \mathrm{~b} の$ 矢印に示す ように，表面㧍よび $\mathrm{Pd} / \mathrm{Nb}$ 界面近傍の粒界からボイドが形成 され始め, ボイドは, 粒界に接する一方の結晶粒側へ拡大し ていった。このことから, ボイド形成拈よび成長には, 粒界

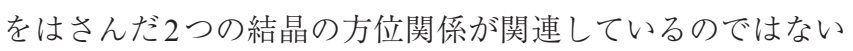
かと考えられる。試料を $500^{\circ} \mathrm{C}$ に保ち続けると, 結晶粒ごと に抜け落ちるようにボイドは拡大し（図15c），ほとんどの ボイドは, 最終的に表面から $\mathrm{Pd} / \mathrm{Nb}$ 界面に至った（図 15d)。 得られた形態は, バルク試料の加熱時に見られる多数の表面 穿孔に対応する構造となった。ボイドの形成は, 試料温度が $500^{\circ} \mathrm{C}$ に達する直前から始まり, $500^{\circ} \mathrm{C}$ に達した後, 初めの 10 分間で進展がほぼ停止し，その後大きな変化は見られな かった。バルク試料に打いても, 同様な傾向が見られること が指摘されており ${ }^{60)}$, 観察された現象はバルク試料での表 面穿孔形成過程に対応していると考えられる。ボイド形成時 に, $\mathrm{Pd} / \mathrm{Nb}$ 界面においては，金属間化合物などの形成を示唆 する大きな組織変化は観察されず，また，試料側面はプラズ

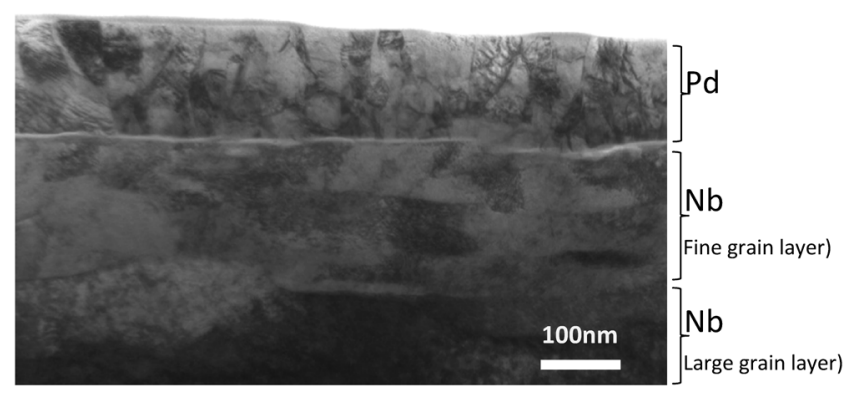

図 $14 \mathrm{Pd}$ 被覆 $\mathrm{Nb}$ 水素透過膜の断面透過電子顕微鏡像
マCVD重合膜で覆われているので，大きな体積変化を伴う 物質移動は考えにくい。ボイド形成時に移動したPdは, 大 部分が表面へ向かって移動したのではないかと考元られる。 さらに長時間のその場観察の結果と, 従来の熱処理試料の断 面観察法を組合せることにより, $\mathrm{Pd}$ 被覆 $\mathrm{Nb}$ 水素透過膜の劣 化過程の詳細が明らかになっている ${ }^{61)}$ 。

\section{5. まと め}

その場加熱実験法, Window型掞よび絞制限型環境セルの 構造を概観した。加熱ホルダに扔いては上野-坂ホルダは超 高温・高分解能での観察に可能性を開いた。また, 伝熱型の 加熱ホルダも，いくつかのメーカによる改良の努力により, 熱安定性・加熱特性が大幅に向上し, 高温でも高い分解能が 得られるようになってきている。環境七ルにおいては，絞制 限型環境七ルが最新鋭の収差補正型超高分解能走査透過型電 子顕微鏡にも取付けられるようになったことから, 多くの成 果が発表され始めている。また, Window型環境七ルにおい ては，2012年以降MEMS加工された窒化けい素膜を用いた ものが市販されるようになり, 多くの研究者が新しい研究を 試みようとしている。

このようなその場観察，とくに環境セルを用いた研究が新 しい局面を迎えようとしている時期に, 我々のこれまでの観 察例を振り返ってみた。真空中その場加熱実験に扔いては, 対象試料や観察領域を安定したマトリックス中に埋込むこと により, 従来不安定で観察困難であるとされていた固・液界 面を原子レベルで観察した例を示した。また, 新規に開発し た可動式環境セルを用いた実験では, 従来考えられてこな かった表面反応現象の断面よりの観察手法を提案し, 銅表面 の酸化挙動, 水素透過膜表面劣化過程の観察例を示した。特 に，4.1節で紹介したような手法を用いた観察は，更に様々 な材料への応用の可能性があり, 名古屋大学超高圧電子顕微 鏡施設 ${ }^{64)}$ を通じて, 試料作製抢よび観察のサービス（有料） を受けることができる。本稿が, 透過電子顕微鏡によるガス 環境中での表面反応の研究に興味をもたれる方々の参考にな

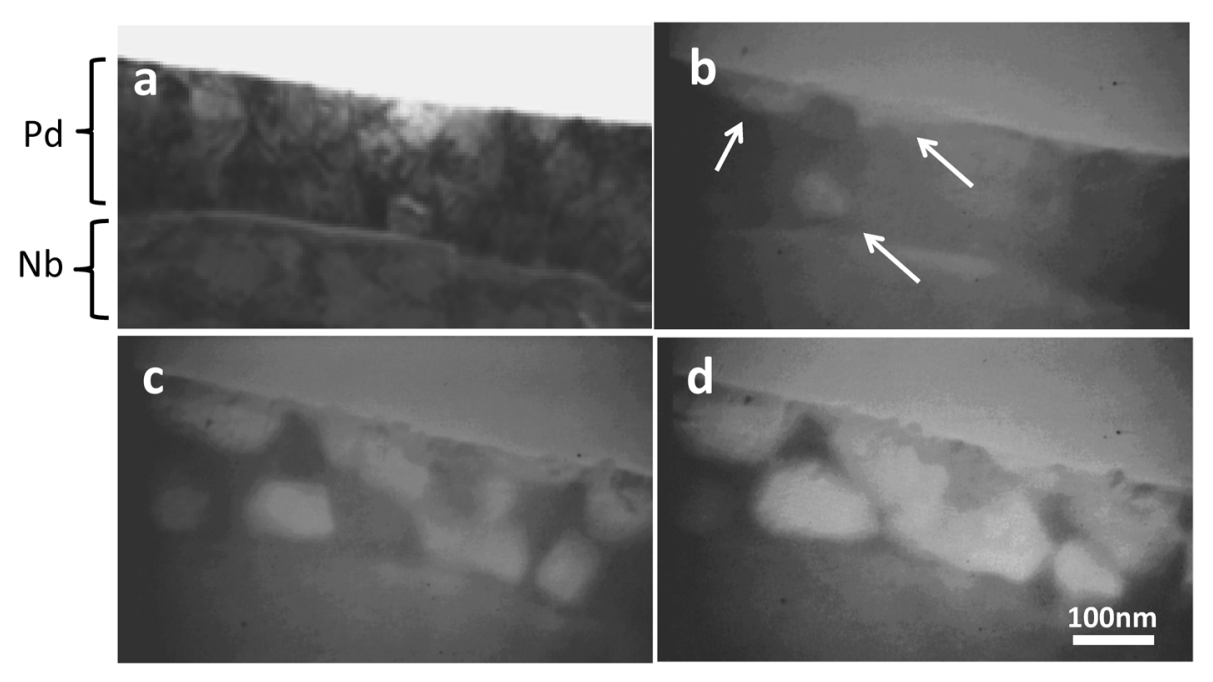

図 15 加熱中の $\mathrm{Nb}$ 基層上の $\mathrm{Pd}$ 層の微細構造変化。（a）加熱前，（b） $500^{\circ} \mathrm{C}$ 加熱 2 分後，（c） 7 分後，（d）9分 30 秒後のボ イド形成過程。(b) 中の矢印は初期ボイド形成箇所を示す 
れば幸いだ。

\section{参 考 文 献}

1) 上田良二：電子顕微鏡，共立出版社，(1982），15.

2) K. Kanaya: History of Electron Microscopes, ed. by H. Fujita, Commercial Exhibition Committee of 11th International Congress on Electron Microscopy, Kyoto, Japan, (1986), 36-42.

3) E. Ruska: Kolloid-Zeitschrift, 100 (1942), 212-219.

4) N. Takahashi, T. Takeyama, K. Ito, T. Ito, K. Mihama and M. Watanabe: J. Electron Microsc. (Tokyo), 4 (1956), 16-23.

5) T. Ito and K. Hiziya: J. Electron Microsc. (Tokyo), 6 (1958), 4-8.

6) H. Hashimoto, K. Tanaka and E. Yoda: J. Electron Microsc. (Tokyo), 6 (1958), 8-11.

7) E. P. Butler and K. F. Hale: Dynamic experiments in the electron microscope, in Practical Methods in Electron Microscopy, ed. by A. M. Glauert, Elsevier, New York, USA, (1981).

8) H. M. Flower: J. Microsc., 97 (1973), 171-190.

9) T. Kamino and H. Saka: Microsc. Microanal. Microstruct., 4 (1993), $127-135$

10) A. Fukami and S. Murakami: J. Electron Microsc. (Tokyo), 28 (Suppl.) (1979), 41-48.

11) K. Ueda, T. Kawasaki, H. Hasegawa, T. Tanji and M. Ichihashi: Surf. Interface Anal., 40 (2008), 1725-1727.

12) D. L. Allinson: Proc. 7th Int. Congr. Electron Microsc., 1 (1970), 169-170.

13) M. Williamson, R. Trop, P. Vereecken, R. Hull and F. Ross: Nat. Mater., 2 (2003), 532-535.

14) A. Radisic, P. M. Vereecken, P. C. Searson and F. M. Ross: Surf. Sci., 600 (2006), 1817-1826.

15) http://www.protochips.com/ ProtoChips社のホームページ

16) P. R. Swan and N. Tighe: Proc. 5th Eur. Congr. Electron Microsc., (1972), 432.

17) J. C. Lacaze, A. Sequela, B. Jouffrey and J. Trinquier: Proc. 5th Conf. High Voltage Electron Microsc., (1977), 145.

18) E. D. Boyes and P. L. Gai: Ultramicroscopy, 67 (1997), 219-232

19) P. L. Gai: Philos. Mag. A, 43 (1981), 841-855

$20)$ P. L. Gai, E. D. Boyesa and J. C. J. Bartb: Philos. Mag. A, 45 (1982), 531-547.

21) P. L. Gai, B. C. Smith and G. Owen: Nature, 348 (1990), 430-432.

22) http://www.fei.com/products/tem/titan/ FEI 社 Titan ${ }^{\mathrm{TM}}$ ETEM $の$ ホームページ

23) H. Yoshida, S. Takeda, T. Uchiyama, H. Kohno and Y. Homma: Nano Lett., 8 (2008), 2082-2086.

24) H. Yoshida, T. Shimizu, T. Uchiyama, H. Kohno, Y. Homma and S. Takeda: Nano Lett., 9 (2009), 3810-3815.

25) H. Yoshida, H. Kohno and S. Takeda: Micron, 42 (2012), 1176-1180.

26) H. Yoshida and S. Takeda: Phys. Rev. B, 72 (2005), 195428-1-7.

27) H. Yoshida, T. Uchiyama and S. Takeda: Jpn. J. Appl. Phys., 46 (2007), L917-L919.

28) H. Saka, T. Kamino, S. Arai and K. Sasaki: MRS Bull., 33 (2008), 93-100.

29) K. Sasaki and H. Saka: Philos. Mag. A, 63 (1991), 1207-1220.

30) K. Sasaki and H. Saka: Microsc. Microanal. Microstruct., 4 (1993), 287-296.

31) T. B. Massalski (Eds): Binary Alloy Phase Diagrams, American Society of Metals, Metals Park, Ohio, USA, (1986).

32) H. Saka, Y. Nishikawa and T. Imura: Philos. Mag. A, 57 (1988), 895906.

33) D. E. Temkin: Crystallization Process, Consultant Bureau, New York, USA, (1966), 15
34) N. B. Thoft, J. Bohr, B. Buras, E. Johnson, A. Johansen, H. H. Andersen and L. Sarholt-Kristensen: J. Phys. D, 28 (1995), 539-548.

35) K. K. Bourdelle, A. Johansen and E. Johnson: Nucl. Instrum. Meth., B118 (1996), 478-482.

36) H. Gabrisch, L. Kjeldgaard, E. Johnson and U. Dahmen: Acta Mater., 49 (2001), 4259-4269.

37) U. Dahmen, S. Hagège, F. Faudot, T. Radetic and E. Johnson: Philos. Mag., 84 (2004), 2651-2662.

38) E. Johnson, M. T. Levinsen, S. Steenstrup, S. Prokofjev, V. Zhilin, U. Dahmen and T. Radetic: Philos. Mag., 84 (2004), 2663-2673.

39) E. Johnson, A. Johansen, C. Nelson and U. Dahmen: J. Electron Microsc. (Tokyo), 51 (2002), S201-S209.

40) J. Chang and E. Johnson: Philos. Mag., 85 (2005), 3617-3627.

41) E. Siem and E. Johnson: J. Mater. Sci., 41 (2006), 2703-2710.

42) K. Sasaki and H. Saka: Mat. Res. Soc. Symp. Proc., 466 (1997), 185190

43) H. Saka, K. Sasaki, S. Tsukimoto and S. Arai: J. Mater. Res., 20 (2005), 1629-1640.

44) S. Arai, S. Tsukimoto, H. Miyai and H. Saka: J. Electron Microsc. (Tokyo), 48 (1999), 317-321.

45) S. Arai, S. Tsukimoto, S. Muto and H. Saka: Microsc. Microanal., 6 (2000), 358-361.

46) L. W. Zhong: Elastic and Inelastic Scattering in Electron Diffraction and Imaging, Plenum Press, New York, USA, (1995), 70

47) S. Tsukimoto, S. Arai and H. Saka: Philos. Mag. Lett., 79 (1999), 913-918.

48) H. Saka, S. Tsukimoto and K. Sasaki: Mater. Sci. Forum, 294-296 (1999), 617-620.

49) T. Kamino, T. Yaguchi, M. Tomita and H. Saka: Philos. Mag. A, 75 (1997), 105-114.

50) T. Kamino, T. Yaguchi, M. Konno, A. Watabe, T. Marukawa, T. Mima, K. Kuroda, H. Saka, S. Arai, H. Makino, Y. Suzuki and K. Kishita: J. Electron Microsc. (Tokyo), 54 (2005), 497-503.

51) N. Tanaka, J. Usukura, M. Kusunoki, Y. Saito, K. Sasaki, T. Tanji, S. Muto and S. Arai: Microscopy, 62 (2013), 205-215.

52) K. Sasaki, K. Kuroda, T. Tokunaga, S. Arai and C. Morita: Proc. 17th Int. Microsc. Cong., (2010), I9.16.

53) K. Sasaki, M. Hattori, S. Arai, K. Kuroda and N. Tanaka: Microsc. Microanal., 17 (2011), 478-479.

54）佐々木勝寛, 服部雅史, 荒井重夫, 黒田光太郎：名古屋大学 電子光学研究のあゆみ 22, (2010), 76-77.

55) K. Ida, Y. Sugiyama, Y. Chujyo, M. Tomonari, T. Tokunaga, K. Sasaki and K. Kuroda: J. Electron Microsc. (Tokyo), 59 (2010), S75-S80.

56) K. Komiya, Y. Shinzato, H. Yukawa, M. Morinaga and I. Yasuda: J. Alloy. Comp., 404-406 (2005), 257-260.

57) D. J. Edlund and J. McCarthy: J. Membr. Sci., 107 (1995), 147-153.

58) D. J. Edlund, D. T. Friesen, B. M. Johnson and W. A. Pledger: Gas Sep. Purif., 8 (1994), 131-136.

59) R. E. Buxbaum and T. L. Marker: J. Membr. Sci., 85 (1993), 29-38.

60) A. O. Busnyuk, M. E. Notkin, I. P. Grigoriadi, V. N. Alimov and A. I. Lifshitz: Tech. Phys., 55 (2010), 117-124.

61) K. Sasaki, M. Hattori, K. Tsuchimoto, H. Yukawa, S. Arai, T. Tokunaga, Y. Murata and T. Yamamoto: J. Alloy. Comp., 573 (2013), 192-197.

62）佐々木勝寛, 服部雅史, 湯川 宏, 徳永智春, 山本剛久, 荒井 重勇：名古屋大学 電子光学研究のあゆみ 24, (2012), 21-24.

63) H. Yukawa, T. Nambu and Y. Matsumoto: J. Alloy. Comp., 509S (2011), S881-S884

64) http://hvem.nagoya-microscopy.jp/ 名古屋大学エコトピア科学研 究所超高圧電子顕微鏡施設のホームページ 